\title{
The Cultures of a Globalized World
}

\author{
Raul Pertierra
}

Contemporary world culture contributes significantly to the crisis of modernity. The global condition has engendered a variety of cultures, each adjusting to its particular condition. Instead of culture being an expression of values, perspectives, and practices within a territory, contemporary culture acts more like a free-floating signifier loosely connected to its material base. Each expression of culture develops according to its own internal logic: high culture vs. popular culture; culture of virtuality \& virtual culture; and local, national, and globalized cultures. Each expression of culture is variedly connected to its material base or spatial configuration. Culture both includes and excludes, depending on notions of normativity and exemplarity. All cultures are autopoesic and complexly related to their specific ecologies.

Keywords: high vs. popular culture, imaginaries of culture, normativity, exemplarity, autopoesis

\section{Introduction}

This paper explores cultures in a globalized world. Hitherto understood primarily as a system of values, practices, and perspectives characterizing a specific group in a given locality or territory, contemporary cultures have become free-floating signifiers only loosely connected to their material structures. Freeing itself from its context, culture is now free to develop according to its internal logic. One example is the distinction between high and popular culture: the former requires increasingly specialized skills while the latter is constrained by more general tastes. This divide between high and popular culture is a major aporia of modernity.

As a free-floating signifier, culture can take many other forms and link a diverse range of collective entities. While sovereign territories can be a basis for culture, necessary ideological ties-nationality or ethnicity-are needed to link their members. Other common bases for culture could be shared perspectives arising from common identities or material conditions. Filipino communities abroad exhibit a diasporic culture formed through common 
identities. The post-modern condition and the new communications technologies provide other bases for cultural formations such as cultures of virtuality (e.g. Second Life members) and virtual cultures (e.g. Facebook). These latter examples are no less real than other forms of culture. They share values, practices, and perspectives. Proximate corporeality is no longer necessary for cultural formations. Hitherto, cultures depended on quotidian face-to-face interactions. Presently, we live in a technologically mediated world. We interact as often with absent others (via technology) as we do face-to-face. It is important to understand the many manifestations culture takes in the contemporary world. While culture always has a material substructure (e.g. a set of practices), it is primarily a collection of representations and hence partly fictive or imaginary.

\section{High culture \& global values}

High culture is generally seen as autonomous practice answerable only to its practitioners and specialized audience. Consisting of highly developed accomplishments, high culture is given a certain freedom from general norms. Hence, Art is answerable only to itself, while popular culture depends more on the conventional practices of its wide audience. Art with its more specialized and limited audience enjoys a relative autonomy from general norms (e.g. sexuality, blasphemy, and commercial success), while popular culture (except for radical expressions) requires broad normative support. As the Frankfurt School argued, popular culture depends on business and commercial interests (Adorno \& Horkheimer, 1989). For Theodore Adorno and his colleagues in the Frankfurt School, popular culture is another name for business, even as it behaves as ideological apparatus for capitalist exploitation, and as entertainment. In Adorno's view popular culture's capacity for extending human aesthetic experience is extremely limited because of severe constraints imposed by commercial interests; radical practitioners challenge these interests. Adorno valued high culture as the major expression of the achievements of global modernity, though he clearly undervalued the originality of popular culture.

While high culture may exercise a limited autonomy, it is nevertheless connected to politics, the economy, and the broader society. Art reflects and generates social values such as esteem which is used by other parties for their own interest. Social, political, and economic elites use high culture as a justification of their status. When first invented, electronic media such as the telephone and radio were initially used to disseminate high culture (Briggs \& Burke, 2010). Germany invented high fidelity radio broadcasting (1935) which was used to transmit classical music and was henceforth associated with Fascist rule. Elements of high culture emphasizing extraordinary 
achievement or heroic values were easily incorporated into elitist rule. The notion of the ubermensch or superman suggested by philosophers like Friedrich Nietsche (Briggs \& Burke, 2010) reinforced the link between high culture and superior achievement. However, the association between high culture and the collective lack a firm basis in the popular imagination; it is difficult to rally a nation using highly aestheticized concepts. The close association between cultural forms and common tastes is better achieved by popular culture and its accessible values and skills. The democratization of society often involves the leveling of tastes more suitable for popular culture rather than the aesthetized sensibilities of high culture (Habermas, 1979).

While modernity is global, it is neither homogenous nor uniform; it includes various expressions depending on social, economic, and historic contexts. In its western manifestation, modernity has largely replaced earlier perspectives provided by religion. This is not the case in countries such as Saudi Arabia and Iran even if they are also exposed to the influences of modernity. The rise of religious Fundamentalism is a response to the secularizing effects of western modernity. While culture framed religious and mythological beliefs, modernity disengaged culture from these structures, allowing it to develop along separate dimensions. In the West, Art (music, painting, \& literature) disengaged itself from religious representation to express secular values and to challenge religious and other mythological beliefs (Levi-Strauss, 1978). This relative autonomy of art is not fully recognized in the Philippines, as indicated by the cancellation of an art exhibit in the Cultural Center several years ago on the grounds that a painting offended religious sentiments. Artistic expression is constrained by the more general requirements of religious sentiments. One of the characteristics of late modernity is the recognition of art as an autonomous field of expression.

Claude Levi-Strauss (1978) argued that the onset of modernity was marked by the demise of most mythological beliefs. Western modernity also saw the rise of classical music such as Frescobaldi, Bach, Mozart, Beethoven, and Wagner. According to Levi-Strauss: music (and presumably the arts) replaced the earlier collective representations found in myths. The cognitive elements of myths, their knowledge, and explanatory claims have been replaced by science, while their affective and sensorial elements are found in music and art. The merging of classical music and mythical themes is best exemplified in Wagner's operas such as the Ring Cycle. Its characters combine extraordinary achievements with superhuman qualities. Their combination is attractive for elites who see power and status as co-terminant. This view is useful for the legitimation of a Unitary State, combining both 
power and legitimacy. In modern democracies, republicans and democrats often debate the necessary balance between exemplary values and popular tastes. In the Philippines, the debate revolves around authoritarian values and personal choice.

Imelda Marcos is an example of advocating high culture for elevating the sensibilities of Filipinos. She established the Cultural Center as a venue for performances of high culture, founded a school for the Arts in Mt. Makiling to train young artists, and generally encouraged Filipinos to develop their aesthetic tastes. This interest matched her approach emphasizing the importance of state institutions, including the Heart Centre and other prominent government bodies. In this view, high culture supports the centrality of the State, and is reflected in Imelda's passion for exemplar edifices (Lico, 2003). In her case, this interest coalesced with personal views about political ideologies supporting her family's grip on power.

Malakas and Maganda represent the polarities of power and legitimacy. The connection between high culture and power attracted German fascists (Adorno \& Horkheimer, 1989). On the other hand, Maoist revolutionaries identified high culture, particularly in its western form, with bourgeois values. Chinese intellectuals and artists were exiled to remote villages to re-learn proletarian values. Despite these varied views of the role of high culture, its importance for modern governmentality is firmly established. In the Philippines, no other prominent politician has matched Imelda's support of high culture though other politicians have exploited the political potential of popular culture (e.g. Erap \& FPJ).

Imelda Marcos's support for high culture suffered a major setback when the family was deposed and exiled overseas. Critics of martial law conflated Imelda's display of wealth with her support of high culture; while the two may be linked, they are not identical. This produced a backlash against high culture that persists presently. Contemporary politicians generally ignore any interest in high culture, and favor its more populist expressions. Only bureaucrats in offices established by Imelda Marcos, including the National Commission for Culture \& the Arts, and individuals with a continuing interest in high culture continue to offer support. As a consequence, the nation's social imaginary has not achieved its full potential.

Necessary features of high culture are mastery of particular skills, and upholding standards. High culture is necessarily global because its standards exceed local and national borders: its practitioners cultivate highly developed skills. Ethnic artists may also contribute to high culture after their achievements are recognized (Jimenez, 2016). For the reasons above, it is important to develop an appreciation for high culture as a source for a national imaginary. 


\section{The rise of popular culture}

Whereas high culture may have exemplary features, it lacks the mass base of popular culture. The expansion of mass media has given popular culture an expanded role in the national imaginary. Drawing on earlier modes of folk culture such as the komedya and sarsuela, (Pertierra, 1995) film, radio, and television make available an almost unlimited number of cultural representations. Enriquez writes that "the music recording and radio broadcast technologies, foreign as they were initially, became the media of an emerging Filipino popular culture" (Sabangan, 2016, p. 81). In 1908, Maria Carpena, a well-known operatic singer from Laguna, was the earliest recorded female artist in the Philippines (Sta. Maria-Villasquez, 2016). Unfortunately, she died (1915) before the ready availability of radio and shellac records became available. But her successors like Atang de la Rama and Sylvia La Torre enjoyed popular fame. This popularity was fully developed by singers such as Pilita Corrales, Nora Aunor, and Sharon Cuneta (Sta Maria-Villasquez, 2016).

In many rural communities, radio still plays a prominent role. Film also played an important part in constituting a national imaginary, but its costs were often prohibitive. By combining visual, aural, and textual images, television effectively transmits popular culture to its mass base. Politicians and others have taken quick advantage of these connections between media and its audience. For this reason politics and consumerism are closely linked (Turner, 2010).

\section{Eat Bulaga as entertainment and politics}

Eat Bulaga has been one of the most successful midday television shows. Recently, one of its subplots (kalyeserye) generated a media phenomenon known as "AlDub" (Pertierra, 2016). This involves formerly unknown actors who unexpectedly developed an onscreen romance that has since taken a life of its own independent of the original TV series. Recognizing its huge fan base, many commentators expressed positive views about this phenomenon, claiming it contains valuable lessons reinforcing traditional elements of Filipino culture such as respect for elders. Those who prefer high culture criticize AlDub as shallow, exploitive, and humiliating.

Despite its clear connections, no one seems to have associated this phenomenon to an equally puzzling aspect of Philippine life-the links between politics and entertainment. The AlDub case poses interesting questions regarding political and social capital. These phenomena draw on collective ties linking individuals to their respective leaders or idols. Journalistic accounts of AlDub generally lack a solid ethnographic analysis of the role Eat Bulaga plays in everyday life as well as the relationship between 
its material context of production and the social context of consumption. Some anthropologists have provided an ethnographic context explaining the basis for their success (Pertierra, 2017b, Lorenzana, 2018).

Recently, anthropology has begun to include analyses of media and the construction of a lived-world (Lorenzana, 2018). Contemporary life is not only suffused with media, but also reproduces itself through media images and practices. We not only live with media but also in media and through media. Watching TV, sending text messages, posting pictures in Facebook, and performing in videoke sessions are not only common forms of entertainment, but also essential aspects of self-representation and construction (Deuze, Blank, \& Speers, 2012). Much of contemporary life is conducted virtually or digitally, connecting subjects spatially separated. Everyday life is based on technologically mediated relationships covering both familiar and non-familiar interlocutors. Contemporary culture both in its global and local versions favor popular expressions rather than more specialized tastes of high culture. The latter may still be seen as elitist and exemplary, while the former reflects more general, non-specialized tastes. Popular culture is also more closely associated with consumerism, a major factor in contemporary society. Scholars such as Nestor Garcia Canclini (1995) and Graham Turner (2010) view popular culture positively: as a site of resistance and innovation.

\section{Consumerism \& entertainment}

Anthropology has also turned its attention to less exotic realities, looking instead at quotidian activities, such as watching TV, hanging out in malls, and engaging in ordinary practices of consumption (Pertierra, 2010). None of these are generally seen as involving deep and significant meanings but are nevertheless essential for the construction and reproduction of the self. These trivialities of everyday life are often viewed as evidence of the superficiality of modernity, and its preference for the merely entertaining in contrast to classical aesthetic standards. The spotlight on ordinary practices of consumption is also viewed as the triumph of the profane over the sacred. Anthropologists have pointed out that the profane and the sacred are two aspects of a common reality (Douglas, 1966); this insight explains the relationship of silly programs like Eat Bulaga with politics, the economy and other more abstract and profound aspects of living. Entertainment media connect the profound with the superficial areas of contemporary life.

Many foreigners are disconcerted by the insistence of Filipinos to mix hilarity with seriousness. Even the most sober Filipino personalities are required to engage in behavior such as singing and dancing to amuse their audience. Miriam Santiago, a politician known for her stern lectures and 
contempt for untutored opponents, delighted her young audiences with silly jokes and even occasionally dancing. Serious talk shows and even academic conferences often include lighter moments when people share jokes and indulge in silly and vulgar comments; sobriety and lewdness are often two sides of the same coin. Anthropologists refer to these practices as rituals of reversal (Turner, 1974). These oblige the highborn to momentarily play the fool as a form of self-deprecation. Displays of self-abnegation reinforce and legitimize social hierarchies; Alterity is a reciprocal and necessary aspect of the self.

\section{Fandom \& politics}

Observers of Philippine life are often struck by the importance of media personalities involved in local and national politics. A sure way of achieving political success is to have myriads of fans willing to vote one into office simply for being well known. Reciprocally, being well-known generates its own fan base. Hence, media stardom and political success reinforce one another. Senator Tito Sotto, a founding member of Eat Bulaga, obtained among the highest votes for the senate in the 2016 elections buoyed by the success of AlDub. Manny Pacquiao, the nation's boxing icon and former congressman, was also elected senator in 2016. They have separate though similar wide and loyal fan bases. Senators Sotto and Pacquiao are politicians and media personalities, so their fans run the gamut from fandom to politics.

While media personalities often come from the entertainment world, others build their popularity by generating collective compassion. The election of Pnoy (Benigno Aquino Jr.) as president in 2012 and the sudden political success of Senator Grace Poe resulted from feelings of collective compassion following the deaths of Aquino's mother and Poe's father. These latter examples share similar structural sources of support as fandom and shared grief. They involve members unknown to one another but drawn together in a common sense of belonging based on a prominent personality or event. Becoming the recipient of collective compassion and occupying a prominent, visible place in fandom and politics guarantee political success. As Benedict Anderson (1991) has pointed out, this sense of individualized collectivity is the basis for imagining the nation. The new communications media has provided a new basis for popularity. The effectiveness of social media in generating such imaginaries is now a familiar event (Pertierra, 2012). 


\section{Televisuality \& everyday life}

Anthropologists such as Leila Abu-Lughod (2004) and Nestor Canclini (1995) revealed the importance of popular culture in generating a national imaginary. Eat Bulaga is not only an iconic example of popular culture; it also plays a quotidian role in representing and experiencing everyday Filipino life. A cursory peek into the average household quickly reveals people watching, perhaps not always intently, their favorite Eat Bulaga segment; Eat Bulaga (and similar talk shows) is part and parcel of people's everyday experience both televisually and sensorially. Given its silly and superficial appearance, how Eat Bulaga achieves this important cultural role requires serious investigation (Pertierra, 2017a).

Popular culture requires more than interpretative approaches to unpack its significance; performance should be seen both as material production and cultural consumption. Popular culture must be located outside itself to identify its sources of power and to reveal its constituting practices. In other words, popular culture must be seen as a component of a broader sociological reality. Otherwise, popular culture remains only a series of shallow representations. Instead, we should view popular culture as a field of practices using images to impose a view of the world, including a position within this world, with the partial consent of its participants.

Culture is both a domain of signification and a field of signified practices. Revealing these practices will expose the sources for their powers of identification (Turner, 2010). The central role of media in merging entertainment with politics is a feature of late capitalism. Do participants in Eat Bulaga consent to their humiliation or do they see their actions as expressions of momentary solidarity? What appears as exploitive from a bourgeois and high culture perspective may express authentic representation by members of the exploited class. In this way popular culture may be an expression of the voice of an otherwise unrepresented class.

How do we account for the deep ties connecting political, religious, and economic structures with seemingly superficial and silly entertainment? Eat Bulaga is able to generate feelings of solidarity and community among its viewers. Guy Debord (1994) views modern society as a series of spectacles or simulacra passing themselves as real. The spectacle is not just a collection of images or representations; rather, it is a social relationship between people mediated by images. This capacity to generate social relations using images illustrates the power of media and its underlying technology. In this sense, Eat Bulaga is as much a creation of social relations using televisual means combined with material distribution as it is entertainment. In other words, Eat Bulaga is a form of politics, using entertainment as its rationale. Here the spectacle and the simulacrum merge creating the real and hyperreal. 
Eat Bulaga is possible only because it depends on the material resources of its sponsors and its consumer base. It is fundamentally a business using entertainment as its form and rationale. The simulacra in Eat Bulaga are politically and economically real. They generate loyalties and redistribute goods. It is also a basis for a national imaginary of which AlDub is an important component.

\section{Cultures as free-floating signifiers}

In a world increasingly without boundaries, culture links diverse groups and collectivities through a complex network of structures, often beyond the nation-state. This influx results in an excess of meaning and a lack of sense (Markus, 1997). Discursive structures are no longer directly related to their productive sources. For this reason, culture adds as much to our disorientation as to our location in the world. Culture is a major contributor to the so-called crisis of modernity. Closely connected to its spatial base in the nation-state, culture acts to justify its ideological unity. Presently transcending its territorial base, culture challenges and subverts its earlier role as unifier of the nation. Modern identities are no longer anchored within the nation-state and following culture's free-floating nature can now locate subjects extra-territorially. Hence, some American born children of Filipino parents refer to themselves as Filipinos from California. An earlier territorial link to the nation-state (citizenship) has been replaced by a personal ethnic identity based on descent (Pinggol, personal communication, July 2, 1995). Other Filipinos point out the inadequacy of conflating ethnicity with nationality (Nagasaka \& Fresnoza-Flot, 2015). Hitherto, the nationstate has been based on a notion of culture that is territorial, homogeneous, and exclusive. Each nation-state possesses a specific national culture that distinguishes it from others. One of its major responsibilities is to preserve and defend its national culture. Cultural borders are established and fiercely defended. Foreign cultural elements are excluded or domesticated and indigenized.

\section{National imaginaries \& virtual collectivities}

What happens to cultures (e.g., national culture) earlier defined as being fixed and bounded? As an important component of the national consciousness, nation-states redefine culture to better suit its present dysfunctions on a nationalism based on historical falsification, inconsistency, instability, and exclusivity. Ernest Renan (1882), the major historian of nationalism, claimed that historical falsification was a necessary component of a national consciousness. In the Philippines, we are familiar with the controversies involving Aguinaldo and Bonifacio about opposing claims for the title 
of father of the nation. To complicate matters, Rizal, the most revered nationalist figure, disagreed with the plan to launch an armed revolt against Spain. The Ilustrados were a fractious bunch who often disagreed with one another (Quibuyen, 1999). These disputes and inconsistencies reveal the problematic notion of a national imaginary.

Since nationalism is essentially counterfactual, it succeeds only by coercing its members into conformity. A nation-state imposes its will through physical force and often terror (hence the Moro wars). Eventually, the nation-state miraculously transforms itself into a seemingly consensual agglomeration of free citizens willing to die in its defense. This transformation is achieved by culture: Anderson (1998) provides us with more details on how this almost magical transformation is accomplished.

What happens to the nation-state when this view of a territorialized and homogeneous culture is no longer tenable? What may be expected when cultural borders are routinely breached and culture fragments into innumerable elements? At the very least, the nation-state must reinvent itself to adapt. It must accept that many of its members adhere to different cultural orientations and ethnicities. Hence, contemporary nation-states must base themselves on pragmatic notions of economic security, social justice, and personal freedom. A booming economy now seems to be the primary legitimation for a modern state. Consumption becomes a civic duty of citizenship. Other elements such as social justice and personal freedom are often subject to dispute and controversy. Nation-states can no longer rely on the myth of cultural unity to justify compliance. These pragmatic notions are based in the historical past or in ethnic and aesthetic commonalities. Moreover, nation-states must now recognize and accept difference.

A product of global interconnectedness transcending national, linguistic, religious, and cultural boundaries, culture is one of the major aporias of our times: it expresses fundamental contradictions in contemporary society, and disorients as often as it locates its subjects. This condition penetrates our traditions and localities, overwhelming them with new signs and meanings elsewhere generated. George Markus (1997) identifies this condition as a surplus of meaning but a lack of sense.

\section{Kalinga \& Kankanai}

Anthropologists used culture to describe the way of life of a particular people. This description includes practices, ideas, beliefs, and material objects that distinguish a people from their neighbors. In this sense, culture is as much a practical orientation to life as it is an awareness of identity. The Kalinga are distinguished from the Kankanai as much by their practices (e.g., 
dress, tattooing, economy \& ritual) as their beliefs. Culture is perceived as a consensual whole adopted because it reflects shared material conditions and ways of life (Pertierra, 1997). A rich Kankanai is beholden to the same cultural norms as his poor neighbor. In this understanding, culture is what people living together share with one another. Sharing a life-world constitutes the basis for this common culture.

When societies become complex and differentiated, sharing a life-world is no longer common or possible. A rich Kankanai may live in Forbes Park, holiday in Paris, and send his children to exclusive schools abroad, while a poor Kankanai ekes a meager living in Ilocos. They may still share an ethnicity but this is no longer rooted in a shared life-world, and hence no longer reproducible. All contemporary societies are complex and differentiated. While modernity is global, it encompasses a variety of incommensurable life-worlds. These incommensurable life-worlds produce distinct cultures, each expressing a manifestation of modernity.

\section{Real territories \& virtual communities}

The nation-state was the first virtual society based on an imagined territorial culture. Earlier territorial cultures based on a notion of a homeland were likewise imagined, but lacked the resources to implement this imagination. Jews are an example of a culture strongly based on a conception of an original homeland. They nourished this conception for millennia but were unable to operationalize it until modern, historical conditions led to the creation of the State of Israel. But not all Israelis subscribe to Judaism. Some are Arabs and others are non-believers. Israel has to find a practical rather than an ideological or political way to reconcile these differences. Palestinians, Kurds, Armenians and other peoples have tried to emulate Israel, but with even less success (Bauman, 2005).

While globalization challenges the cultural basis of nation-states, it also, paradoxically, provides for ethno-nationalism, the expression of other cultural formations. As the nation-state's cultural homogeneity fragments, distinct cultural units seek protection from national sovereignty (e.g., MILF \& MNLF). As argued by some scholars, opponents of colonialism often employed colonial models for their own purposes. Arjun Appadurai (1995) has argued that in opposing the nation-state, these new cultural formations insist on reproducing themselves through similar means. It appears that territoriality is often the ultimate goal of certain cultural formations. Forms of materiality (e.g., territory, economy, language, religion) are often necessary for culture to represent itself. Should we see the MNLF, MILF, as ethnic entities that wish to transform their imagined, virtual homelands 
into geographic territories? Is it possible for ethnic entities to seek virtual rather than geographic territories? Filipinos in diaspora presently interact in digital space, thus generating virtual territories.

\section{Crises in modernities}

Sociologists refer to these problems as the crisis of modernity; culture is its most acute expression. Other major expressions are the crisis of overproduction and environmental degradation. These crises began in the nineteenth century and resulted in the separation of areas of life into private and public spheres, each sphere governed by its own set of norms. In The Work of Culture (Pertierra, 2002), I tackled some of these questions and explored manifestations of culture in the contemporary world. While culture seems to be everywhere, it no longer locates its subjects anywhere. Airports and tourists encapsulate this non-locating culture. Airports create spaces in transition, where tourists can act as transitory locals. The architecture of airports emphasizes locality as well as passage. Some areas display local icons while other spaces represent unobstructed passage and mobility. Tourists are locals momentarily transiting in foreign places before returning to their communities.

In a world increasingly globalized, the role of culture has become problematic. The idea of a global culture is unable to reflect its inevitable diversity. From expressing collective orientations and values, culture marks difference. In a world characterized by a surplus of meaning and a lack of sense (Markus, 1997), culture's capacity to provide a shared lens or framework for society is seriously challenged. As the world becomes progressively more interconnected, a common basis for understanding disappears. Only local and contingent perspectives are viable and even these are often globally constituted. As Sherry Turkle (2012) and Stephen Marche (2012) have argued, while we are increasingly interconnected, we remain alone: this is a paradox of the modern condition.

\section{The local, national, and global}

No wonder modernity is ontologically insecure and constantly in search of threats and solutions. Culture presents a world full of unfulfilled aspirations juxtaposed with real achievements. While local culture is closely related to experiences and routines of everyday life, it also includes pre-reflective bases for inequalities involving gender, age, class, and ethnicity. Locality abhors and creates hierarchies of difference: men above women, seniors above juniors, rich over poor, Caucasians over people of color, professionals over the unskilled. 
National culture is less directly connected to everyday experience and consists predominantly of normative and exemplary rules imposed by schools and governments. Ernest Renan (1882) argued that national culture is often imperative, coercive, and intolerant. National culture is mainly counterfactual and relies on myth and other mechanisms to enforce its precepts. Despite these contradictions, a national culture can be very powerful and altruistic. The monument of the Unknown Soldier stands as a symbol of the stranger protecting the motherland (Anderson, 1998). The altruism of the stranger unifies the nation, all of whose members stand for one another.

Global culture is experienced vicariously rather than directly and acts as a powerful incentive for new values, norms, and orientations. Its vicarial nature encourages excessive expectations in contrast to the banality of daily life. All these uses of culture generate their own aporias. Local culture is unaware of its pre-reflective assumptions and is thus unable to question basic inequalities. National culture imposes its values on resisting minorities and insists on homogenization to further its own ideological purity. Global culture promises a world of new pleasures and commodities located in a space-time unconnected to other aspects of daily life. Global culture creates its own virtual world with an excess of meaning and a lack of sense.

\section{Sociologies of culture}

The industrial revolution created the conditions for the period of early modernity between 1750 and 1850 (Ochial \& Hosoya, 2012). Wage labor dominated everyday life and society became differentiated into relatively autonomous areas: business, politics, religion, and culture, each with its own discourse. Earlier, pre-modern culture was embedded in everyday life and provided the context and parameters for behavior. Modern culture separated itself from other areas of life, and thus no longer provides an overall guide for behavior. Appropriate action depends on context (e.g., business, religion, family) that brings its own set of norms. An example of such a clash of norms concerns the recent case of a Filipino wife who accused her husband of having illegally acquired wealth while in government employment. Her duties as a wife to support her husband and to preserve the family's honor clashed with her obligation as a citizen to denounce corruption. Her duties in the domestic sphere clashed with her obligations in the public sphere. A single moral code no longer applies across distinct social contexts. In the case of the Philippines, these autonomous areas are not clearly demarcated, resulting in cross-normative expectations. What is appropriate in a business transaction may go against family norms of mutual assistance, or may contravene religious beliefs (e.g., excessive profits or usury). The institution 
of the family crosses what should be seen as autonomous areas. Political power, religious office and social esteem are transmitted through familiar connections crossing otherwise autonomous areas of culture and society The family remains as a relic that has survived the transition from premodernity to modernity.

Modernity has disconnected culture from its embeddeness in everyday life. Modern culture expresses the ideals for accomplishment in various areas (e.g., art, science, sport), and represents the most valuable ideas and the most refined sensibilities or achievements. Modern culture also consists of representations in the form of entertainment to fill in the short periods of leisure in an otherwise work dominated world. Culture in the form of art or entertainment is a cathartic response to a mechanized and pragmatic life-world.

Following Karl Marx (1867), wage labor produced a culture of alienation and commodification: the fundamental conditions within which modern culture operates. This is the context for the bitter critique of culture found in Dialectic of Enlightenment by Adorno and Horkheimer (1989). This book was written when the authors lived in Los Angeles during their exile from Germany. Despite its publication in 1944 (in German), it remains the most exhaustive critique of the culture of modernity (Freeman, 2017). According to Adorno and Horkheimer (1989), culture as entertainment becomes an industry governed by the need for profit. Like other businesses within capitalism, the culture industry, exists both to extract surplus labor and to impose the alienated condition of workers. Hollywood, Fox News, and other media players exist to create profit; the byproduct is an ideological apparatus justifying exploitation. Technology mainly serves this same exploitive purpose. Underlying such structures is the limited understanding capitalism has of a rational worldview-instrumental reason and the ceaseless pursuit of profit. Jurgen Habermas (1979), while agreeing with many views of the Frankfurt School, has offered an alternative by arguing that modernity also has the capacity for communicative rationality - the desire to achieve a common understanding of a state-of-affairs. A condition where ego and alter incorporate each other's perspective in order to arrive at a common understanding. While most structures in capitalism operate on the basis of instrumental reason (ego is mainly interested in achieving his goal irrespective of alter's position), very few instances and institutions allow for communicative rationality e.g., psychoanalysis, academic discourse, areas of civil society. But even these areas are increasingly encroached upon by the expanding needs of capitalist reproduction and political domination. 


\section{Histories of modernity}

The culmination of early modernity (1880-1940) generated a public sphere dominated by the nation-state with its fixed borders and a national economy (Ochiai \& Hosoya, 2012). The private sphere was controlled by the patriarchal family and women's role was confined to the home and childrearing. In the second phase of modernity (1970-2017) the individual replaces the family and locates itself within a global culture. Members of the generation in between (1940-1970) experienced a significant transition marked by a time of relative affluence and full employment in the West. This generation also witnessed a growing awareness of individual rights in the spheres of race, sexuality and employment. The growing influence of popular culture (film, music, radio \& television) generated a more segmented consumer market based on gender, generation, race and class. This was accompanied by a demographic shift from rural to urban areas. Urbanity replaced the gentilities of rural society. The old regime was coming to an end even as members of this transitional generation were largely unaware of its replacement. But the growing demands of women and minorities, sexual liberation and postcoloniality indicated that the world was changing significantly. The growing importance of the youth as a separate category (between childhood and adulthood) became an important element of popular culture. The youth have lost the innocence of childhood but are not yet ready to embrace the obligations of adult life. They represent a generation in transition best expressed in popular culture. Many countries now recognize the needs and interests of the youth-teenagers are an important feature of popular culture. In the Philippines, this was marked by the visit of the Beatles in 1966 resulting in teenage mania. Eric Gamalinda (1992) vividly describes this event, based on local media, as one of the largest demonstrations during the Marcos regime. Ironically, it also marked the public humiliation of Imelda Marcos by the Beatles' refusal to perform at Malacañang.

In the second phase of modernity (1970-2017), individual rights override the family and intimacy dominates everyday life (e.g. a discourse of the emotions and affect). While globalization was earlier seen mainly in economic and political terms, it is now primarily cultural (which explains its current populist rejection). The borders of the nation-state are more porous as people move in search of new opportunities. International institutions such as the World Bank and the United Nations now shape national economies and politics. Popular culture permeates all areas of the world. Rap may have started in the black neighborhoods of New York but is now found in Kabul and Cubao. In addition, we are becoming increasingly aware of our own intervention in nature. The Age of Anthropocene locates 
humans as the prime actors in the social and natural worlds (Latour, 2014).

\section{Lower birthrates \& women's emancipation}

The first and the second phases of modernities were shaped by demographic declines: reduced fertility, improved sanitation, and compulsory schooling (Ochiai \& Hosoya, 2012). The first phase produced the rise of childcentered families with a strong gender division of labor: men went out to work while women stayed home; housework became unpaid labor (18801940). Marriage and long-term relationships became the norm. The family and domestic matters were the center of private life, while the state and civil society attended to collective rights. In Australia, the family wage was introduced in 1905, and the male wage earner was expected to maintain his family. Patriarchy became the basis for domestic reproduction.

Post 1970, the second demographic decline produced smaller families. The increasing use of labor-saving domestic technologies facilitated the introduction of women into the workforce. Combined with the introduction of effective contraceptives, women's bodies became part of the public sphere where previously they were considered under patriarchal family control. Divorce weakened the traditional family structure, while the rise of more liberal sexual norms resulted in the emancipation of the individual from the control of the patriarchal family. This second phase of modernity came into full swing between 1970 to 2017 with the communication revolution and the emergence of the so-called children of the internet.

This second phase is also characterized by the globalization of everyday life and the transformation of the sphere of intimacy through a discourse of the emotions or affects (Giddens, 1992). The rapid adoption of mobile phones and the rise of social media generated a private sphere with open and direct access to the public sphere. This interaction between private-public was centered on individuals and networks rather than earlier collectivities such as the family and locality. The state and civil society encroached on the private sphere, and the universal declaration of human rights was adopted across national boundaries, social classes, and gender identities.

\section{The birth of the individual}

According to Emiko Ochiai (2012):

In Western Europe and North America, laws and systems that presume that the individual, not the family, is the unit of society are being codified; these laws and systems are based on the idea that individuals should not be treated differently according to their choices of lifestyles, including 
While these changes are not yet fully implemented in the Philippines, their influence is apparent in the increasing acceptance of the rights of members of the LGBT community, and their representation in congress. The media now commonly include examples of unorthodox unions, such as same gender weddings or the sexual activities of transgendered people without a whisper of scandal. While these examples mostly involve media personalities made popular by unconventional attitudes, the examples reflect significant changes in empowering individuals to pursue alternative lifestyles. The recent implementation of reproductive rights, over the objections of the Catholic Church is yet more evidence that we are moving towards a transformation of intimacy from the private to the public sphere. New media facilitated the transformation of intimacy from the private to the public sphere; it is now almost impossible to monitor social media user experience. Did technology merely facilitate this transformation or did the technology create the intimacy?

While culture previously provided its members with limited choices, present-day local and global culture offer a wide choice, involving combinations of our own making. A recent issue of National Geographic Magazine (January 2017) offers its readers a choice of seven gender identities (intersex non-binary, transgender female, bi-gender, transgender male, androgynous, male, female). These identities involve distinct performances, affiliations, and orientations. Identities can evolve or revert to earlier forms. Some involve gender reassignment surgery while others only require a readjustment in behavior and orientation. We are not only the authors of our own lives but we are also its designers (Myerhoff, 1978). The range of choices is bolstered by the availability of consumer products; the diversity of cultural choice is closely allied to its consumer base. Consumer choice requires equally wide cultural preferences; therefore culture remains wedded to its material expressions. In capitalism, culture is a freewheeling set of signifiers that stimulate consumption. Consumer choice not only involves material goods but also corresponding cultural identities. Consumption becomes the main concern of citizenship (Canclini-Garcia, 2001).

\section{Always connected but alone}

According to Zygmunt Bauman (as cited by De Querol, 2016):

The question of identity has changed from being something you are born with to a task: you have to create your own community.... The difference between a community and a network is that you belong to a community, but a network 
belongs to you. You feel in control. You can add friends if you wish, you can delete them if you wish. You are in control of the important people to whom you relate. People feel a little better as a result, because loneliness, abandonment, is the great fear in our individualist age. (para. 3)

Is the difference between the first and the second phase of modernity simply one of emphasis or does it involve a qualitative change? Is the generation of the 1990's significantly different from their parents and grandparents who also experienced disruptive epochs, including the Japanese occupation (1943-45), the end of colonialism, and the advent of Philippine independence? Or did these disruptions merely initiate the transformation from a national to a global condition? The generation before the children of the internet also experienced the onset of a global age. Mass media such as television, film, and radio were firmly established and the exodus of overseas workers had begun. Important political and cultural events were taking place: the Cuban missile crisis (1962), the assassination of President Kennedy (1963), the student revolts in Paris (1968), the sexual revolution, and the ascendance of teenage culture. All pointed to important social transformations. The highlight was the highly successful visit of the Beatles to Manila in July 1966 but the band's refusal to perform in Malacanang prevented the fusion of high and popular culture.

In contrast, the second phase of modernity involves new economic, political, and cultural transformations. Markets, politics, and culture transcend national borders. Globalization creates new structures that cast the world as a synchronic entity (e.g., digital time). A global consciousness re-examines local cultures and reveals their flaws and limitations. Culture itself is seen as contentious, arbitrary, hegemonic, and incomplete. A new global civil society impinges directly on individuals. This intrusion of the global into the local often generates a conflict of norms. Filipinos adapted global standards against cruelty to animals, and demanded an independent film's exclusion from a prestigious festival. The controversial scene featured an inhumane and cruel animal death. On the other hand, dog meat is a common delicacy and an essential part of ethnic culture in some regions.

\section{Language as a floating signifier}

I would therefore claim that we are approaching the dawn of a new civilization whose explicit aim will be to perfect collective human intelligence, that is to say, to pursue indefinitely the process of emancipation into whose path 
language has thrown us. (Levy, 2011,p. 4)

Pierre Levy (2011) points out the emancipatory potential of language which hitherto has been constrained by multiple practical, material, and cultural factors. Women, children, and the poor were silent. Only refined speech was appropriate in the public sphere, and this was mostly masculine. President Duterte seems to be able to breach this rule but even he is constrained when addressing certain audiences (e.g., children or minors).

Culture and language have always been closely connected; one affecting and being affected by the other. What happens to language when culture is loosely connected to its previous structures? When detached from previous cultural constraints, language is free to develop along new lines. This is what happens with the new media. No longer under the old cultural constraints, the language of new media takes new forms, often challenging previous normative boundaries. New media has opened up new avenues for discourse, allowing us to say the unsayable, think the unthinkable, and establish heterodox relationships. Not only do we interact with countless absent others (including robots), but we also interact with the technologies that make all these activities possible. Their usage also shapes us.

We live in a technologically mediated world in two senses: technology opens new worlds, and shapes us through our interactions in these extended worlds. The virtual was earlier seen as an inferior version of the actual, however, now, the virtual is an indispensable adjunct that constitutes and enriches the real. Virtual reality is no less real than actual reality. In some ways, the virtual displaces the actual, replacing it with its simulacrum (Baudrillard, 1988).

New communications media disrupt earlier perspectives and countless examples of the disruptive effects of social media-from facilitating the spread of fake news, encouraging criminal and immoral activities, and threatening social life-occur frequently. However: new media have also facilitated and encouraged the democratization of discourse and information. No longer under the control of traditional gatekeepers such as the mainstream media and other institutions, new media serve as the expression of previously silent minority voices.

Culture is now individually generated as people author their lives according to tastes, desires, and circumstances (Hannerz, 1993). Material accumulation becomes a major way of self-expression. Consumerism is as much a process of self-construction as it is public display (Cohen, 2017). Most of us conduct our lives both online and offline. How do we combine these two modes without one unduly distorting, dominating, or reproducing the other? Virtuality is now an aspect of everyday life and we must contend 
with its vagaries (Pertierra, 2018b).

\section{The ontology of media \& representations}

Increasingly, media become invisibly incorporated into our lives. Life outside media is now impossible. But life in media means that social reality is always under construction, revision, and rejection. Identifying who participates in this process of social construction is one of the most contested issues. Is Wikipedia a reliable source of knowledge or should only the experts dictate what we can know?

Individuals and institutions look at social reality as under permanent construction-as something to intervene in, redirect, manipulate, and transmutate at the level of genetic modification. The remixabilty of the real has become a property of lived experience, and questioning reality is the first and most fundamental step towards changing it (Deuze, 2012b). This understanding of culture as under permanent construction is what makes modernities essentially unstable even as it also provides the basis for ensuring their continuity (Luhmann, 1998).

\section{Final comments \& summaries}

Culture, however flawed, inconsistent or problematic, remains an essential element of modernities. Anthropologists studied culture in societies where beliefs, norms, and practices were closely intertwined. Culture, arising from common material factors, defined a way of life shared by all its members. In complex societies, this unity between cultural practices and life-worlds or lifestyles began to diverge. Complex societies consist of a plurality of orientations and discourses, which enjoy partial autonomy from one another. The nation-state managed to coalesce many of these divergences by imposing rigid conditions for their expression. National culture was an imagined reality imposed by organs of the state. The nation-state is the first virtual society based on an imagined territorial culture. Globality seems to $\mathrm{ha}^{\mathrm{ve}}$ disengaged culture from its local and national roots, and locate itself in complex networks. Many of these networks are spatially dispersed but intimately connected, overlapping with local and national cultures.

Another feature of culture in modernities is the search for exemplarity or coextensiveness. Cultural expertise is found in all societies including pre-modern ones such as the T'boli (Jimenez, 2016). This expertise plays a formative role in the constitution of national cultures (Sabangan, 2016) where both exemplarity and coextensiveness are achieved through new communications technology like radio and music recordings.

Cultures continue to thrive under diverse conditions. The world of 
representations, however linked to its material foundations, finds ways of reproducing itself. As Luhmann (1998) argued, culture is autopoesic-it reproduces itself through internal mechanisms as well as through its connections with its external world. The evolution and expansion of social life enables cultures to establish new environmental linkages. As a consequence, contemporary life has taken many forms to generate cultures in modernities.

High culture is often linked to structures of the State and its notion of power, exemplarity, and excellence. Physical structures indicate the State's authority, as well as shaping its urban lifestyles. Baron Haussmann's (1850) reconstruction of Paris in the 19th century is a prime example of designing urban landscape to reflect governmentality. An aspect of this governmentality is the need for consumption, a-role required of citizenship. Citizens must be active producers and insatiable consumers. The trinity of power, myth, and the state is meant to constitute a common culture, but the replacement of high culture by popular culture prevents their harmonious integration. Hence, the practical anchorages of meaning have been disengaged from everyday life, creating a surplus of meaning but a lack of sense. The rise and significance of virtuality, fake news, post-truths, and hyper reality are a consequence of the disengagement of meaning and sense. Culture perpetuates but is unable to bridge this discontinuity; culture is the consequence as well as the cause of the crisis of modernity. 


\section{References}

Abu Lughod, L. (2004). Dramas of nationhood: The politics of television in Egypt. Chicago: University of Chicago Press.

Adorno, T. \& Horkheimer, M. (1989). Dialectic of enlightenment (J.Cumming. Trans). London:Verso.

Appadurai, A. (1995). The production of locality. In R. Fardon (Ed.), Counterworks: Managing the diversity of knowledge (pp. 220-245). London: Routledge.

Anderson, B. (1991). Imagined communities. London:Verso.

Anderson, B. (1998). The specter of comparisons, nationalism, Southeast Asia and the world. London:Verso.

Baudrillard, J. (1988). Selected writings. Palo Alto: Stanford University Press: Palo Alto.

Bauman, Z. (2005). Liquid life. London: Polity Press..

Briggs A. \& Burke P. (2010). A social history of the media; From Gutenberg to the Internet. Cambridge: Polity Press.

Canclini-Garcia, N.(2001). Consumers \& citizens:Globalization and multicultural conflicts. London:University of Minnesota Press.

Cohen, D. (2017). "More is more," Empire of things: How we became a world of consumers, from the fifteenth century to the twenty-first by Frank Trentmann Harper. The New York Review of Books. Retrieved from https://www.nybooks.com/articles/2017/05/25/consumer-society-more-is-more/.

De Querol, R. (2016, January 25). Zymunt Bauman: Social media are a trap. El Pais. Retreived from https:// elpais.com/elpais/2016/01/19/inenglish/1453208692_424660.html.

Debord, G. (1994). Society of the spectacle (N. Smith trans.). London: D. Zone Books.

Deuze, M., Blank, P., Speers, L. (2012). A life lived in media.Digital Humanities Quarterly 6(1).Retrieved from http://www.digitalhumanities.org/dhq/vol/6/1/000110/000110.html.

Douglas, M. (1966). Purity \& danger. London: Penguin.

Enriquez, E. (2016) Popular culture in the Philippines at the time of Maria Carpena. Sabangan 2, 78-81. Manila: Philippine Women's University.

Freeman, S. (2017, March 23). The headquarters of neo-Marxism. The New York review of books. Retreived from https://www.nybooks.com/articles/2017/03/23/frankfurt-school-headquarters-neomarxism/.

Gamalinda, E. (1992). The empire of memory. Manila: Anvil Publishing.

Giddens, A. (1992). The transformation of intimacy: Sexuality, love \& eroticism in modern societies. London: Polity Press.

Habermas,J. (1979) Aspects of the rationality of action. In T. Gereats (Ed.), Rationality today: Proceedings of the international symposium on rationality today Held at the Univ. of Ottawa, Oct. 27-30, 1977. University of Ottawa.

Hannerz, C. (1993). Cosmopolitans and locals in world culture. Theory, Culture, \& Society, 7, 237-51.

Jimenez, E. (2016) Sounding the spirit: The life of the T'boli T'nonggong. Sabangan 2, 37-50. Manila: Philippine Women's University.

Latour, B. (2014). Anthropology at the time of the anthropocene. Retrieved from http://www.bruno-latour. $\mathrm{fr} / \mathrm{sites} /$ default/files/139-AAA-Washington.pdf.

Levi-Strauss, C. (1978) Myth and meaning. London: Routledge \& Kegan Paul. 
Levy, P. (2011). Collective intelligence: Mankind's emerging world in cyberspace (R. Bononno, trans.). London: Helix Books.

Lico, G. (2003). Edifice complex: power, myth, and Marcos state architecture. Quezon City: Ateneo de Manila University Press.

Lorenzana, J.A (2018). Effervescence, resonance and emotive practice on social media: Public expressions of heartbreak among young Filipino Twitter, In A.S.Dobson, et al., (Eds.), Digital intimate publics and social media. London: Palgrave.

Luhmann, N. (1998). Observations on modernity (W. Whobrey, Trans.). Palo Alto: Stanford University Press

Marche, S. (2012). Is Facebook making us lonely? The Atlantic. Retrieved from https://www.theatlantic.com/ magazine/archive/2012/05/is-facebook-making-us-lonely/308930/

Markus, G. (1997). Antinomien der kulture. Lettre international., 13-20.

Marx, K.(1867).Das Kapital: Critique of political economy. Book I:The production process of capital. New York: LW Schmidt.

Myerhoff, B. (1978). Number our days. New York: Simon \& Schuster.

Nagasaka, I. \& Fresnoza-Flot, A., (Eds.). (2015). Mobile childhoods in Filipino transnational families: migrant children with similar roots in different routes. London: Palgrave .

Nietzche, F. (1967). Ecce homo (W. Kaufmann, Trans.). New York: Vintage.

Ochiai, E. (2012). Introduction: Reconstruction of intimate and public spaces in Asian modernity. In E. Ochiai \& L. A. Hosoya (Eds.), Transformation of the intimate and the public in Asian modernity. London: Brill.

Pertierra, A.C. (2017a). Televisual experiences of poverty and abundance: Entertainment television in the Philippines. Australian Journal of Anthropology (2), 21-38.

Pertierra, A.C. (2017b). Media anthropology for the digital age. London: Polity Press.

Pertierra, R. (1995). Philippine localities \& global perspectives. Quezon City: Ateneo de Manila University Press.

Pertierra, R. (1997). Explorations in social theory \& Philippine ethnography. Quezon City: University of the Philippines Press.

Pertierra, R. (2002). The work of culture. Manila: De La Salle University Press.

Pertierra, R. (2010) Anthropology of new media in the Philippines. Quezon City: Institute of Philippine Culture, Ateneo de Manila University.

Pertierra R. (2012). The new media, society \& politics in the Philippines., Fesmedia Asia. Berlin: Friedrich Ebert Stiftung. Berlin.

Pertierra, R. (2016). Anthropology \& the AIDub nation. Philippine Studies, 64(2), 289-300.

Renan, E. (1882, March 11). Qu'est-ce qu'une nation? Paper presented in Sorbonne conference, Paris.

Sta Maria-Villasquez, G. (2016). The nightingale meets Nipper the dog: Maria Evangelista Carpena and the beginnings of recorded music technology in the Philippines, ca. 1900-1915. Sabangan 2, 64-77. Manila: Philippine Women's University.

Turkle, S. (2012, March 30). Connected, but alone? [Video file]. Retrieved from https://www.ted.com/talks/ sherry_turkle_alone_together?language=en. 
Turner, V. (1974). The ritual process. Penguin, London.

Turner, G. (2012). Ordinary people and the media, theory, culture \& society. London: Sage

Quibuyen, F. (1999). A nation aborted: Rizal, American hegemony and Philippine nationalism. Quezon City: Ateneo de Manila University Press.

RAUL PERTIERRA is a visiting professor at Ateneo De Manila University as well as Philippine Women's University. Pertierra mainly teaches graduate courses in anthropology/sociology at the Ateneo and supervises ethnomusicology majors at Philippine Women's University. He has published extensively in foreign as well as local journals on topics such as social theory, culture and politics. Before his retirement in the Philippines, he held professorships in Australia, Singapore,TheNetherlands and Finland. (corresponding author:rpertier@mozcom.com) 